\title{
A apostasia comunista: a subjetividade como política
}

FernandoKolleritz

\author{
Universidade Estadual Paulista-Franca
}

RESUMO:

Edgard Morin (Auto-critique), Annie Kriegel (Ce que j'ai cru comprendre) e Claude Roy (Moi, je) percorrem passo a passo, desde a infância, as trilhas que olevaram ao PCF; os três participaram da resistência anti-nazista aolado da União Soviética, ocasião da entrada em comunismo. Seguem-se as descriçóes de uma lenta asfixia moral em que os depoimentos fazem perceber como a rede das necessidades internas à subjetividade. Este artigo, analisando as autobiografias de três intelectuaisfranceses no momento em que dão criticamente conta de seu passado comunista procura apreender a figura bistórica toda negativa da relaçãoa sinas assim chamadas"contra-sociedades comunistas" durante operíodo stalinista.

Palauras-Chave: Autobiografia; Indivíduo; Regime Polútico; Stalinismo.
ABstraCt:

Edgard Morin (Auto-critique), Annie Kriegel (Ce que j'ai cru comprendre) and Claude Roy (Moi, je) go over step by step, since childbood, the tracks that took them to the PCF; the three of them have participated in the anti-nazism resistance, on the Soviet Union's side, occasion of their entrance in communism. Descriptions of a slow moral asphyxia are given, in which the statements show bow the net of internal needs of political ideology ends up echoing in the net of the internal needs of subjectivity. This article, analyzing the autobiographies of three French writers in the moment when they give a critical account of their communist past, tries to apprebend the entirely negative bistorical figure of the relation to oneself in the socalled "communist counter-societies" during the stalinist period.

Keywords: Autobiography; Individual; Political Regime; Stalinism. 
"O pano de fundo obscuro do estritamente dado, este pano de fundoformado por nossa natureza imutável eúnica, surge na cena política como o intruso que na sua impiedosa diferença vem nos lembrar os limites da igualdade bumana".

(HannabArendt)

“Ostalinismo não constituía somente um erro, um desvio, um engodo político; sentia, já, que era ainda pior: uma mutilação e uma mutação do bomem que punba em causa os próprios fundamentos da existência". (EdgardMorin)

Um livro em boa parte autobiográfico e, ao mesmotempo, obra coletiva de muitos testemunbos, caía como um raio, há vinte e cinco anosjá, ferindo as consciências européias: o Arquipélago Goulag.

Por que cessa bruscamente-após décadas de surdez e de "pálpebraspesadas", de indiferença renitente diante das denúncias provindas da antiga URSS desde os anos vinte-a obstinação na ignorância voluntária? Talvez se possa defender que a tendência libertária marcada nos anos sessenta, com sua notável inflexão individualista, tenba aguçado a sensibilidade dos intelectuais europeus e da opinião pública em geral face à dimensão singular de memórias, autobiografias e depoimentos. A onda individualista do pós-68 beneficiou não só ao "eu" narcísico e egoústico: ficamos também mais atentos e sensíveis à ótica pessoal, ao valor de verdade que testemunbos, em sua singularidade, comportam. Contra os abusos da teoria, que tanto tempo se fizera soberana, a memória e o sofrimento passaram a valer como medida de verdade. Ao ouvirmos depoimentos, assinaríamos um pacto com a subjetividade contemporânea, reconbecendo aos sentimentos e prismas individuais, capacidade para alcançar a verdade, paradiscriminar entre o bem e o mal. É que, como as bistórias que seguem o ensinam, todo mundo tem sobressaltos morais; nem todos porém alcançam os arcanos da dialética... 
Outrasmemórias, outras autobiografias além da de Soljenitsyne, versando sobre a cultura e as sociedades comunistas, escritas por quem com elas conviveu, constituem um enorme manancial de estudo e reflexão. Contribuem todas, ou deveriam contribuir, para recompor nossos borizontes ético-políticos.

Oregime instalado a favor da revolução bolchevique de 1917 deu ensejo, no bojo das transformações históricas, a desenvolvimentos surpreendentes nas artes e nas técnicas da engenharia da alma bumana; estas, aliás, espalbaram-se posteriormente por boa parte do mundo. Mesmo onde o comunismo náo triunfou e náo revolucionou a sorte das populaçóes, em países como Itália, França ou Brasil, os partidos comunistas existentes, constituídos em autênticas contra-sociedades ${ }^{2}$, conseguiram mudarmaneiras desentir e agir dos seus quadros, militantes e simpatizantes, numa dimensãojamais apreciada em suajusta medida.

Para nos aproximarmos destas questóes retivemos três testemunbos autobiográficos de ex-resistentes e de ex-militantes comunistas europeus, os de Egard Morin, Annie Kriegel e Claude Roy ${ }^{3}$ É a narrativa da relação da consciência a si mesma (ao self) que aqui nos interessará.

Este tema pode ser tratado como integrando de par em par uma bistória política: aparece, de fato, nos três autores, como contestação à outra subjetividade, a do Partido leninista. "Creio que em profundidade o devir das formas coletivas e o devir das formas pessoais se iluminam um ao outro, compóem as duasfaces de uma mesma bistória do Sujeito", escreve Marcel Gauchet ${ }^{4}$; a espécie de confronto entre subjetividade individual e imperativos coletivistas do stalinismo poderá constituir um bom vetor para ilustrar a fórmula do autor.

Tratar da subjetividade como um elemento do político é mais do que legítimo. Afinal, os regimes socialistas pretenderam, abolindo antigas relaçóes de produção, estabelecer sociedades menos individualistas do que as burguesas, sociedades em que a relação de cada qual a si mesmo fosse mediada por um coletivo promotor da realização plena, fúsica e psíquica, dos trabalbadores. Pretendiam substituir à preferência por si dos proprietários individuais tal qual tende a desabrochar no capitalismo, senti- 
mentos de solidariedade correlatos à integração na produção coletiva. Prometiam, em suma, construir o bomem novo. Tal projeto considerava que, ao defender a propriedade privada e seu controle sobre o trabalbo, a burguesia favorecia o predomínio nefasto de um excessivo amor de si, a antecedência egoústica do cuidar de si, o privilegiamento da vantagem pessoal, expressão de uma atenção a si particularista, de uma precedência inoportuna na preferência do que me é próprio. A sócio-economia desdobrava-se, assim, numapsicologia social.

A pergunta permanece pois, em primeiro plano, bistórica. $O$ que adveio "realmente"? Que traços, que configuração a relação a si ganbou nas sociedades e nas contra-sociedades comunistas? O bomem comunista de quem se prometia, neste prisma coletivista, fazer um bomem novo, pôde se aceitar, estimar a si mesmo, confiar em si, e cuidar de si? Em que medida e sob que formas? Ora, aos olbos comunistas haverá sempre o risco contra-revolucionário de se preferir ao todo, de incorrer nas seduçóes do espírito possessivo e da preferência de si sobre os outros.

Reunir esses três escritores, muito próximos na geração e nos itinerários, em torno da reflexão sobre subjetividade e política, não é fruto do acaso. O processo de apostasia dá-se, para eles, sobre bases bastante similares. Integraram uma mesma cultura política, defenderam ideais, estratégias, táticas e métodos, sem que o partido ao qual pertenciam detivesse no país o monopólio do uso legal da violência, sem que os ameaçasse, portanto, a presença física do terror; sem receio, para sermos claros, de torturas, de campos ou de prisóes. A tradição bolchevique, mesmo sem necessidade de recorrer a aparelbos policiais e repressivos de Estado, subverteu radicalmente a relação a si, em função de uma lógica interna à ideologia e às práticas do aparelho. Por outro lado, os comunistas aqui evocados participaram durante a última guerra mundial do movimento de Resistência contra a ocupação alemã. Se a passagem pelo stalinismo só deixou aos três um completo e radical repúdio, a participação na Resistência, em contrapartida, permaneceu reivindicada como ação ético-política, justa no seu princípio e oportuna no seu momento, 
juízo e decisáo de agir que nunca foram questionados 5 . Ação inteiramente assumida, plena de eticidade e inteiramente política.

Não são, assim, as informaçóes históricas ou mesmo a reflexáo analítica concernindo o marxismo e o sistema comunista que poderiam em primeira máo interessar-nos. Um outro aspecto pareceu mais especificamente relevante. Aqui, deixamo-nos interpelar pelo que as autobiografias quiseram propriamente significar, isto é, pela narrativa de um itinerário pessoal, e em primeiro lugar-topos que constitui o lugar por excelência da autobiografia-pelas mudanças advindas à personalidade do escritor.

Aautobiografia implica em simesma uma valorização da subjetividade ${ }^{6}$. Neste nosso caso, porém, os textos concernidos não se contentaram em ilustrar implicitamente esta avaliação positiva, fizeram das dimensóes da subjetividade um tema-núcleo, tornaram a relação a si um leit-motiv. Ler-se-á nestes textos um elogio axiológico da subjetividade, um ponto de partida para constituiro bem comum. Ao longo do percurso, de fato, a narrativa de vida tornou-se a defesa de uma certa relação a si, assumiu caráter normativo. Porque pretendeu "assumir-se inteiramente responsável por si mesmo", Claude Roy escreve com bumor que reinventou o estoicismo; nesta brincadeira engana-se de quinze ou vinte séculos e teria dito melhor que redescobrira o direito subjetivo ${ }^{7}$.

Como algo em princípio tão simples, tão irrecorrível quanto o sentimento de si pôde se tornar, para alguns, nestes anos do após-guerra, a baliza e a guia de uma posição política? Eis pois a questão à qual a particularidade destes gestos autobiográficos nos convida. Resume noplanoda vivência individual um terrível aprendizado: a fúria da História que os homens fizeram, extraviados em seus entusiasmos mais generosos. Notemos, enfim, que as três autobiografias não advogam, no seu tom, inocência; invocam, no máximo, as circunstâncias atenuantes de um "enlevo de geração", como diria Kriegel.

O grau de urgência com que a noção de subjetividade se fez aí presente não mobiliza explicitamente a tradiçãojurídico-política em que a singularidade individual se reivindica comofonte ética; surge, antes, em razão da radical interdição que sofrera a subjetividade na experiência militante destes três escritores. As 
bistórias pessoais de que tratamos não se desenrolam, em suma, simplesmente "face" aos acontecimentos: aojulgá-los, os testemunbos engajam a própria relação a si.

VALORES E AMBIGÜIDADES DO DESAPEGO DE SI

Ofio essencial das narrativas evocadas consiste pois em encontrar as razóes pelas quais, na visão destes escritores, entrouse e permaneceu-se um prazo sempre demasiadamente longo no Partido, as tendências singulares e coletivas em razão das quais cometeu-se o erro e o mal da militância comunista. A Auto-critique de Edgard Morin, redigida logo após o rompimento com o partido, permanece mais estreitamente circunscrita a este tema. Claude Roy (progressivamente, à medida que avança na sua trilogia) e Annie Kriegel, quando escrevem, já estão mais distantes, no tempo, da antiga militância e, se o móvel essencial do que Ihes provoca a escrita gira centralmente em torno de uma paixão política e do seu repúdio, o tema apresenta-se neles menos sensivelmente onipresente, de tom sem dúvida mais sereno.

O sentimento de um drama pessoal, advindo da História, náo está, entretanto, ausente em nenbuma das obras: para justificar seu empreendimento autobiográfico, Kriegel expressa-se em nome de "um irreparável que me aconteceu"; ter assistido "ao mais abominável encadeamento de desastres que o mundo conheceu" aumenta com a dor de não ter sabido, ou não ter podido, evitar tomar neles a sua parte. Quando evoca os processos abertos nas democracias populares contra antigos dirigentes comunistas (em particular durante ocaso Rajkna Hungria em 1949), salienta o peso de sua responsabilidade, "prisioneiros como estávamos", escreve, "dos mecanismos que nos fizeram pessoalmente cúmplices - com dezenas de milhóes de outros pelo mundodestes abomináveis sacrifícios bumanos" .

A autobiografia começa pela reminiscência e evocação das origens; rememora a bistória dos pais, seu pertencimento social e ideológico, suas aspiraçóes morais, sobretudo a influência que deixaram, a educação que transmitiram. A busca destas presenças no interior de si mesmo, no entanto, só adquire sentido no gesto biográfico caso se queira nelas designar a berança interiori- 
zada de uma sensibilidade, ou, ao inverso, caso se tencione acentuar o repúdio destas influências. De qualquer modo, o "eu" recebeu, já, uma forma social, nunca mais estará realmente sozinbo, dialoga-se até ofim, diz Charles Taylor, com aqueles que para nós contaram; laços inter-subjetivos são atados e com eles algo como compromissos afetivos e morais estabelecem-se.

Annie Kriegel valoriza, na sua experiência, o ambiente familiar: nãofosse a guerra, a necessidade de deixar Paris ocupada, imagina-se outra perspectiva para a jovem e aplicada aluna, até então muito bem integrada em sua família, seu bairro e seus estudos. Não guarda de fato senáo gratidão aos pais, à educação que Ihes deve, ao gosto que transmitiram de um saber dotado de prestígio adquirido na disciplina do traballbo cotidiano; por outrolado, as referências àsmolas ideológicas do pai, judeu assimilado, adepto de um republicanismo de esquerda, enunciam-se de modo todo positivo. A Ocupação alemã, cortando os laços sociais babituais da adolescente judia, precipita o ingresso no mundo adulto da clandestinidade, pesa com toda sua carga fortuita sobre esta trajetória onde nenbuma veleidade de rejeição cultural, de revolta geracional se anunciava; existência nova, a contrapelo e a contracorrente do que a sociedade "normal" continua a viver, neste mundo secreto que ninguém, mesmo os mais próximos, parentes, amigos, devem intuir. "Náo chegara ao comunismo pelo marxismo nem por qualquer tipo de percurso intelectual. No essencial, e até o ápice dos meus anos stalinistas, chegara a ele por razóes que dependiam antes de tudo da conjuntura bistórica e política."

Morin, inversamente, evoca ofluxo das idéias do imediato pré-guerra, “os grandes tropismos que me empurraram, como tantos outros, a romper com a família e a sociedade, buscar a vida nova, ir ao encontro do risco e da aventura, unir a iniciação ao mundo à experiência revolucionária..." . Roy, por sua vez, relembra esses anos 1930 em que besita entre Marx e Maurras, neste ambiente polarizado, maniqueísta e apocalíptico onde o regime republicano encontra tão poucos defensores...

Entre meus três personagens há uma diferença de idade que, por pequena que seja, no meio da tormenta, conta. Claude Roy, o mais velho, já fizera a si mesmo todas as perguntas que o conflito 
mundial, com a ocupação nazista em especial, virá atualizar: Annie Kriegel não tivera ainda a ocasiáo, noprimeiro ano de guerra, de iniciar oseu processo de separaçáo da família. De qualquer forma, como o expressa Morin, "a guerra viera perturbar o reencaminhamento apaziguador e inerte dos adolescentes nos passos deseus pais." Oevento imprime-se aqui com a força de um destino pessoal.

Não é somente a força dos acontecimentos que sela o itinerário destes jovens; assim, quando encontra pela primeira vez um membro comunista da Resistência, Roy é advertido "que entre minba família, minha carreira, meu conforto e o Partido, era o Partido que devia daí para a frente estar sempre em primeiro lugar". Em outros termos, cultiva-se um desapego de si explicitamente ideológico; as normas do aparelbo comunista instalam como regra principal, com um radicalismo inaudito, com método sistemático, uma espécie de indiferença a si, um descuido de si que é, também, dádiva de si. Está em pauta o apego a certos valores, individualizantes ou individualistas, que convém eventualmente sacrificar: A clandestinidade do resistente exige sem dúvida o abandono das comodidades pessoais, outrossim, só se torna bom comunista quem se impregna verdadeiramente de uma ideologia bolchevique, quem se desprende de si, do burguês ou do pequeno burguês que habita cada qual, tara de origem ou de formação. Os perigos da ação clandestina nãofazem senão reforçar a ideologia identitária do partido do proletariado.

Poucos dentre os resistentes não se tornam, mais cedo ou mais tarde durante a guerra, clandestinos; largam atrás de si nomes, profissóes, endereços, amigos, parentes. Aprendem até a exaustão a perder o passado, a memória, a si mesmos. A profissão, afamília, os laçossociais não importam mais. Vivem exchusivamente em função dos seus fins ético-políticos. A luta contra o ocupante, e pela libertação, possue-os inteiros. Patriotas, oferecem a vida pelo país. O despojamento ilimitado, o esquecimento de si pode, literalmente, ir até ofim. Defendem uma entidade substancial, a pátria, e defendem nela, para ela, algo incorpóreo, espiritual: a liberdade. Uma configuração semelhante reflete-se no ideário utópico dos comunistas. Luta-se pelo advento universal de uma classe, luta-se pela sua emancipação, para que desdo- 
bre sua existência em liberdade. De certaforma, opós-guerra celebrou como gesto cívico por excelência a atividade resistente, exaltou nela a renúncia à vida privada e pessoal, admitiu que náohavia mellbor modelo ético que o sacrifício de si à coletividade nacional. Uma forma de renúncia de si identificou-se à forma eticamente mais acabada do sentimento político. Há experiências políticas, mesmo extremas, violentas, em que a subjetividade é exaltada.

A Resistência foi uma ação voluntária de poucos bomens, por isso facilmente tornados exemplares. Configura um modelo de comportamento singular e de atitude individual, festejado, celebrado e idealizado de cima a baixo portoda a sociedade, das elites ao proletariado, próximo da abnegação beróica. Adedicação à causa coletiva desdobra-se nas medidas de um apaixonado e exaltado esquecimento de si. Um modo político de viver foi alcançado que serve de espellbo moral, que designa a dimensão bela, justa e verdadeira do dever cívico, ato simples, ao alcance de todos, próprio do sentimento de ser francês.

Celebrada e comemorada, a ação resistente trouxe novos foros de legitimação aos sentimentos comunistas. A “ilusão do comunismo" no pós-guerra europeu não se nutre assim apenas de sentimentos negativos, do ódio ao burguês e do ódio de si ${ }^{10}$. O revolucionário comunista recebeu para o reforço da sua militância o respaldo da ação resistente, quando o auto-sacrifício vale na verdade como realização plena de si.

Riscos existem, vale advertir, nestas formas-limites do agir político. Recusar a existência na qual cada um se inscreve por filiação, por pertencimento social, pode equivaler a uma espécie de denegação do passado e de suas marcas; pode tornar leve demais, livre em excesso, pois que sem lastros, sem ancoragens, sem apegos. Filbos de ninguém, a quem indifere o sexo, a nação, as idades, as aptidóes, as circunstâncias individuais. Negar elos de pertencimento incide no risco de desacreditar das raízes bumanas e arrancá-las. Há perigos, bem se sabe, nogosto da utopia: considerar brancas as páginas bumanas pode levar a políticas de terra arrasada. Há nas dimensóes éticas e políticas, com certeza, uma prudência antropológica a adquirir. 
Por isso mesmo, oparalelo que traçamos entre a ação resistente e a comunista náo pode ser, do ponto de vista que nos interessa, mantido sem fortes ressalvas. A Resistência defendia uma realidade bistórica objetivada: território sobre o qual um poder soberano se estabeleceu, demarcado por fronteiras, país e paisagem dotados de aura, nação símbolo de união, legado, Pátria a que se deve uma filiaçáo; aos revolucionários, cabia devolver a esta berança a liberdade que lbe é própria. Estas densidades identitárias, elos e compromissos cuja contingência aparece sob forma de um destino comum, define um lastro subjetivo. Em vez disso, o acerto interno da subjetividade comunista, cujo substrato (a bumanidade universalmente conciliada consigo mesma) ainda será criada, bá de encontrar outras referências e definições.

Nosso problema poderia agora ser posto nestestermos: saber em que medida o desapegar-se de si na busca de um objetivo políticoserá humanamente enriquecedor, representará um ganboético.

A apostasia será de qualquer maneira um sacrifício autêntico: ao deixar o Partido, os ex-militantes deixaráo a organização com a qual e graças à qual deram, resistentes, o melbor de si. Não à toa, condutas tergiversadoras face ao comunismo realmente existente conotam ainda boje as posiçóes de inúmeros intelectuais de esquerda. Não é casual, inversamente, que o ex-militante comunista torne-se estridente nos seus discursos quando descobre a patogenia dos regimes comunistas e suas próprias responsabilidades que a cegueira de sua crença comportava.

\section{OS SUJEITOS DESPOSSUÍDOS}

Até a guerra, Morin e Roy aproximam-se do mundo das ideologias desprendendo-se dos seus laços sociais e familiares num processo misto de consciência-inconsciência em que ambos se detêm longamente. Assim, oprimeiro:

(...) eu me sentia só, incompreendido (escondia a aflição que queria tantotivessem adivinhado), inimigo da minha família. Todos os meus esforços ideológicos, a partir de quatorze anos, foram em um certo sentido tentativas para escapar à solidão e à culpabilidade, e recolocados em questão, num momento ou outro, pela erosão da dúvida ${ }^{11}$. 
O estatuto das escolbas parece, à primeira vista, sempre beterogêneo. De um lado, idéias e ideais aos quais se adere engajando-se livremente num movimento político; do outro, bá necessidades verdadeiramente pulsionais (o partido representa para nossos autores uma família, uma camaradagem), tendências psicológicas, atrações e motivações profundas, "mecanismo", “transferência”, evidentemente inconscientes, "da salvaçãoparticularpara a salvaçãocoletiva".

Edgard Morin descobre nas suas inclinaçóes comunistas uma parte de messianismo; elas têm, reflete, porveia secreta, a tentativa de voltar a encontrar a mãe que perdeu muito criança. Remetendo a zonas de sombra, a um dinamismo invisível de projeção, Morin tenta compreender-senãojustificar-a profundidade e o peso de uma fidelidade esmagadora, de uma servidão militante, salientando o quanto, no meio à ação mais escolhida, a consciência se reveste do seu duplo inconsciente. Afetos, desejos e ideologia sáo, de uma certa maneira, o mesmo; atingem apenas camadas diferentes da estrutura e da existência pessoal.

Sua adesáo ao partido comunista possui do mesmo modo um embasamento moral ignorado e secreto. Tratar-se-ia de outra coisa, pergunta, no que respeita a devoçáo ao partido, do que expiar este crime de ter "matado" a mãe, assassinatofantasmático que, julga, foi-lhe necessário tentar resgatar? Agir, nesta perspectiva, não é algo que obedeça somente a juízos e decisóes plenamente transparentes.

Nesta linguagem psicanalítica (que Morinaliás acaba de descobrir), é toda uma maneira de ver o mundo que assoma, onde afetos e sentimentos morais revelam-se uns pelos outros, onde a moralidade, indiscernível da afetividade, é sempre também uma psicologia; onde, sobretudo, a experiência adulta, lúcida, escoIhida, compreende-se a partir do que subsiste da infância como memória em ato e "insiste" como efeito do inconsciente. A presença deste paradoxo-até que ponto tenho liberdade no sentimento, e que moral posso ter sem liberdade? - não é minimamente incompatível com o gênero memorialístico.

Os conteúdos da introspeç̧ão praticada na Auto-Critique ficam por conta e risco, evidentemente, de seu autor; para o que 
nos ocupa, ressalte-se o seu significado antropológico. Resgatar a culpa do assassinato fantasmático da máe, diz aproximadamente Morin, encontrou uma forma de expressáo na militância comunista. A escollha da consciência-sujeito, da consciência-ciência no campo ético-político duplica-se da presença do ser desejante, dos seus apelosoriginários, das suas reaçóes afetivas às respostas dosoutros. $\mathrm{Na}$ lógica interna desta auto-análise rememorativa, nãose desencarnem as idéias, nãose abstraia das ideologiaso pensar doservino, emotino e afetivo que ainda e sempre, embora em plano recuado, babita-o. $O$ servivo, de necessidades e carências, prediz-sejá, pormeio da mediaçãoda sensibilidade, comoser demoralidade.

O sentimento, está claro, desempenba papel essencial nas narrativas autobiográficas. Náopoderia ser deoutra maneiraquando predomina o prisma subjetivo na tarefa de configurar o mundo. Ou, circularmente, é preciso dispor de uma noçáo como o sentimento para que o prisma da subjetividade possa desdobrarse plenamente. Lábil, fluido, ele tem a virtude essencial de se adequar sem problemas a toda sorte de objetos; pode-se amar "similarmente" a mãe, uma música, um bicho, uma casa, a Pátria, a Lei, o próximo e o Líder; em suma, o sentimento une esferas díspares da existência. Por outro lado, representa um mediador ideal entre o puramente somático e o idealmente mental.

De modo semelhante, ajuizar tampouco pode ser considerado operação puramente intelectual. Morin confessa só se ter decidido a favor do comunismo logo após a vitória russa em Stalingrado. "Stalingrado varria para mim todas as reticências... Sim, Stalin é genial”. As primeiras vitórias alemãs pareciam da mesma maneira trazer o veredito sem apelo da História. O escritor sente-se premido a dar ao evento tal qual este se impóe na realidade o sentido do definitivo e, portanto, do verdadeiro. As forças que triunfam (ou parecem triunfar num dado momento) traduzem a verdade da História, negá-las equivale a colocar-se fora do mundo, a confessar uma impotência. É, em primeiro lugar, por procedimento teórico begeliano que Morin sacrificou suas posiçóes aos eventos bistóricos: estes representam um momento da racionalidade absoluta e da necessidade bistórica. Deixa manifesto, entretanto, que também psicologicamente se sente 
movido, persuadido pela segurança emotiva que o êxito (a razáo do maisforte, portanto) comporta. Otemor de se sentir alienado do real leva a aderir ao fato tal qual aconteceu, a vitórias, mesmo que pareçam subjetivamente injustas. Tal submissáo à racionalidade do real iria até o suicídio: de origem judia, colocadoface à vitória "irreversível" dos alemães, esteve prestes a entregar-se à policia nazista, endossando os interesses "racionais" dos franceses vencidos, tentados, com a colaboração, a diminuir os custos daderrota.

O ato intelectual é babitado por um imperativo de realismo; este, porém, não constitui meramente uma forma da inteligência, deixa-se penetrar também pelo medo de perder pé na História, de ficar alijado do curso político. Oprocesso de pensamento, tornado uma espécie de pulsão realista e pragmática, é excluído da consciência. Os aportes da atividade cognitiva encostam-se assim em uma espécie de oportunismo caracterial. Morin nos descreve, um depois do outro, o movimento sacrificial dojovem judeu francês à razão de Estado, e do jovem comunista à Revolução; ao fazê-lo, indica como o conbecimento intelectual aloja-se no mais profundo de uma interioridade, esposando as dobrase os contornos da afetividade.

Os anos 1930-1950, segundo nosso autor, repartem-se entre tentações nibilistas e ímpetos religiosos enredados na "História":

(...) sem raiz, estava apto a viver esta contradição, submetido a todosos ventos de idéias, já que minha orfandade havia acentuado minhas necessidades de fervor e meu sentimento do nada. São ao mesmo tempo impetos de juventude e traços de caráter que mefizeram aderir ao comunismo stalinista. Traços decaráter: falta de confiança em minhas próprias forças, pessimismo imediato, otimismo dofuturo, messianismo ${ }^{12}$.

A própria época acolhe e discrimina certos caracteres, elege algumas sensibilidades; não somente o "eu" não se pertence, por existirem as dimensóes do inconsciente, como o próprio contexto prepara, para cada um, um destino adequado, ou não, à sua medida; o aleatório deste encontro entre época e caráter evoca algo como a noção de destino pessoal, de sina individualizada. 
Roy nãofala outra linguagem. Ele também encontrou no Partido um substituto representante do pai, ele também afirma ter deslocado sua fé cristã para uma religiosidade política.

Demorei anos para desenovelar a asfixiante rede de substituiçóes na qual me enredava: perseguidor (aristocrata) e perseguido (masoquista), pedindo ao monarca ou a Partido, ao chefe ou ao dirigente para ser este Pai que nem meи pai, nem Deus haviam consentido ser ${ }^{13}$.

Experimenta longamente "desenraizar(...) o que na sua psicologia contaminava a sua ideologia”, distinguir, do que pertence à História, "sua pequena história pessoal". Oengajamento dáse ao mesmo tempo como ofruto de especulaçóes teóricas e como uma sensibilidade psico-ideológica que o empurraria para "os revoltados, os vencidos, os perseguidos, os idealistas".

Annie Kriegel, em contrapartida, não recorre à linguagem psicanalítica; aborda as questóes relativas à identidade remetendo, antes, aos pertencimentos coletivos. É através deste prisma que explica afetivamente a integração ao Partido: “(...) após ter perdido

212 patronímio, moradia, rua, escola, profissáo, [ele] era uma margem para onaufragado. Eraabordar à terra firme de um paísseguramente imaginário, mas em certa medida já definido e concreto"'14. Este encontro só adquire evidentemente relevo e significadopara quem foi, em abrupta ruptura, expulsa da sociedade instituída.

Para a autora, a identidade comunista recobrira e absorvera, por infortúnio, uma identidade francesa e republicana de uma parte, judia da outra. Sáo suportes essenciais aos quais o Partido, por suas práticas, leva a renunciar. Este agride uma realidade identitária que resulta de um passado coletivo, de pertencimentos simbólicos; ele dissolve diferenças ao tentar construir o bom militante e disciplinar suas energias. Basta, aliás, escreve a bistoriadora, um "Iustro ideológico superficial e sumário" para secretar uma "consciência de classe" e "um espírito de partido". Partidolar, Partido-abrigo, meio ecológico, mundo à parte que fomenta uma maneira de ser, fabrica uma "alma comunista".

Mas as coisas não são tão simples assim. Kriegel salienta que nem todos são igualmente inclinados a dispor de sua identidade; para alguns, para osjudeus, afirma, podia se tratar de uma verda- 
deira necessidade psico-social. "Osjudeus estavam demasiadamente vulneráveis para não substituírem a própria identidade pela identidade comunista"15. Face àqueles que lhes traziam uma causa universal englobante, face àqueles que lhes ofereciam os meios de combater por sua dignidade e de, simplesmente, sobreviver, não tinham os judeus uma dívida de gratidão?

Roy, Morin, Kriegel voltaram, para narrarem a si mesmos, à infância è̀ adolescência; ratificam assim a moderna tradição (que Rousseau exemplarmente consagrou) pela qual só nos aproximamos realmente de um "eu próprio" contando sua bistória, considerando o seu engendramento no tempo. Será aliás difícil, conforme uma tese central de Temps et Récit, diferenciar o sujeito e a narrativa que o conforma ${ }^{16}$. Sendo assim, o movimento da apostasia é sem dúvida revelador: desvela ao mesmo tempo a finitude da dimensãobumana no campo moral-pois se auto-designa dependente da afetividade e das influências ético-culturais do tempo-e comprova, nesta mesma análise e descrição, suficiência necessária para se alçarà altura de uma racionalidade universal.

SENTIMENTO MORAL

Sabe-se o quanto a questão da subjetividade foi central na prática dos militantes. "Durante anos”, resume Morin, "zombamos das ilusóes e dos inchaços da subjetividade" . Lembremos como tal atitude (que concerne ao mesmo tempo o conbecimento e a moral) tornou-se possível.

Avulgata marxista tornou-se pré-ciente ao desprender de uma teoria dos modos de produção e de uma análise sócio-econômica do capitalismo a antecipação certa de um futuro histórico. Os partidos comunistas e as vanguardas revolucionárias apropriaram-se desta verdade futura tornando-se seu suporte e vetor politicos. Náo é preciso insistir sobre este misto, explosivo, de determinismo e de voluntarismo; em função dele, partidos e vanguardas tornam-se afiançadores do que define a necessidade objetiva. Praticando uma ação objetivamente necessária, banbam, como o próprio Morin faz observar, num meio de verdade: mais do que "ter" o monopólio da verdade, o Partido "é" seu substrato. Desta "epistemo-lógica" nasce a própria noção de subjetivismo. 
Toda subjetividade (reflexo puro da objetividade) pertence, como monopólio seu, ao partido. Face à instância coletiva de verdade (que nãofaz senão ocupar olugar ideal do proletariado), dúvidas e besitaçóes, críticas ou denúncias terãoforçosamente caráter "subjetivistas". Graças ao sufixo depreciativo, a instância da subjetividade é abolida do político. A reforma que pretende a criação de um Homem Novo obriga a ir muito além de corrigir opinióes "errôneas" ou “falseadas": deve eliminar a simples menção ao subjetivo, lugar e substância do erro, do divisionismo e de um pluralismo anárquico, espaço ínfimo da relaçáo a si, fenda minúscula onde fermenta-fonte de todos as ilusóes-a supervalorização das intençóes, dos conbecimentos e dos sentimentos pessoais, “desvios”, por certo, pequeno-burgueses.

Assuspeitas que a subjetividade enfrenta tornam-se mais claras e circunscritas com a noção de moralismo. "Éramos naturalmente levados a desacreditar de toda moral autônoma. Esta não poderia ser senão sentimentalismo, subjetivismo, medo do real", escreve ainda Morin ${ }^{18}$. É preciso almejar a eficácia voluntariosa, em algum grau sempre violenta, dos meios propriamente políticos para atingir verdadeiramente a emancipação bumana onde reside a moralidade última; desta vontade, o Partido, instrumento de guerra revolucionário, torna-se o meio bipostasiado.

Como o sentido moral não deve faltar, com seus padróes próprios, aos membros do Partido, assimilar-se-á o dos oponentes a sentimentalismos complacentes, objetivamente nocivos. Trata-se de saber reconbecer, nos infortúnios e sofrimentos trazidos pelas decisóes do Partido, sacrifícios que o tempo presente requer como necessários, que preparam ademais um futuro de felicidade. É aí aliás que tudo se decide, pois diante do que é inevitável, dúvidas morais só podem ser vãs. Odevir bistórico, indefectível, que se bá, porém, de enxergar e pôr em obra, tem o poder de apagar asvidas concretas, de rebaixállas à ordem do náo essencial. Para uma só necessidade determinada, um só sujeito designado capaz de se adequar a ela: o Partido. Outras subjetividades só podem ser dispersivas, digressivas, supérfluas, quando não malignas.

Por oposição, a crítica à experiência comunista conduziu a uma exigência dramática de reabilitação da subjetividade e 
da autonomia moral. "Censuram-se os ex-stalinistas”, diz a Autocritique,

(...) por serem amargos, agressivos, desmesurados em relação à antiga fé, é que guardaram ou enfatizaram o sentimento de enojamento que surgiu um dia no núcleo mesmo de sua experiência. Evidentemente, este sentimento só tem valor se se recombecer a subjetividade como uma quarta dimensão do mundo social (...) $)^{19}$.

A subjetividade assume-se como um direito intrínseco à ética. Completemos a última citação:

Pela primeira vez minha consciência ousou sentar-se notribunal supremo...este sobressalto de consciência, esta recusa da impostura, mesmoque tão somente mental, salvava minha razão. Achama da indignaçãoera a úmica coisaqueclareava minha noite: era alucidez

Adimensão moral irrompe como sobressalto de indignação, algo profundamente meu, fibras morais, vísceras éticas. A espontaneidade cunba a existência de um sentimento moral individual fora do qual a esfera ética não chega a se constituir. Ou: impropriedade de um campo ético sem a dimensáo pessoal que lhe traz autenticidade. De certa forma, pela autenticidade que auferem, pela sua denotação existencial característica, os sentimentos qualificam-se como critérios de verdade e de moralidade.

Para quem vem dos borizontes mentais comunistas, este gesto (o de ouvir a consciência) não é simples. Contesta uma espécie de tabu do pessoal, empenbando contra as dimensóes da bistória e das suas necessidades as de uma individualidade singular... "Temia em demasia não opor à bistória senão o meu drama individual”. Eleger a própria consciência como dimensão privilegiada da ética significa outrossim, para ex-militantes, abdicar de uma espécie de pudor da moral: "moralmente, rejeitava o sistema, mas ideologicamente rejeitava minha moral"2o.

Ter-se-á observado a reiteração dos possessivos, exatamente aquilo que Morin comunista rejeitara. A reapropriaçáo do que Ihes é "próprio" evidencia-se dificultosa para aqueles que viveram como se só bouvesse ética quando pública e obedeciam à 
evidência de que não bá propriedade, mesmo a de si próprio, senão nefasta.

Tal extremo a que Morin diz ter sido levado, e que o obrigaria a escolber entre loucura e razão, sublinha a unidade do "eu": o choque moral leva à lucidez intelectual. A sensibilidade afetiva, as emoções e os sentimentos ("sobressalto", “indignação") não perturbam o intelecto; o afeto emotivo exprime-se ao contrário como sintoma de um pensar adequado.

"Sobressalto moral", descreve Morin. É o mesmo que afirmar uma adesáo a si mesmo, a algo de próprio, de meu, no instinto e no instante, submissáo ao presente e ao concreto. Face a esta atitude nominalista, a linguagem do Partido falseia-se de antemão visto que implica, por obra de suas mediações abstratas, um distanciamento muitas vezes perverso da realidade, contestado precisamente pela emoçáo moral. A ideologia tornou-se uma forma de relativização do real que ofende o sentimento moral.

No que diz respeito à ação pratica, é da boa distância ao real que se trata: a emoção, enquanto é dimensionada pelo aqui e 216 peloagora, enquanto é momento particular de uma singularidade, potencializa-se, ao que tudo indica, para sermais verdadeira do que as abstrações ideológicas. Mas, não o esqueçamos, o sentimento náo é aqui valorizado em si; trata-se de uma forma outra de racionalidade, de um respaldo para a lucidez; com estas conotaçóes, ele seria, sim, um bom aferidor de real, capaz de exprimir o justo ou o injusto. A invasão de Budapeste pelos soviéticos, o processo contra Rajk - "ele náo podia ter cometido os crimes de quefoi acusado,"1 - comportam reaçóes emotivas que asseguram e confortam a razáo, que reconduzem à verdade do empírico. A emoção e a subjetividade têm seu lugar na pólis.

Nas três autobiografias, o afastamento progressivo em relação ao comunismo é referido precisamente como possibilidade de acesso a real. "Minha lenta retomada de contato com o real", escreve Annie Kriegel ${ }^{2}$. Os tempos militantes fizeram perdero sentido do real pelo uso casuístico e falseado dos dados empíricos, de argumentos descritivos e prescritivos inextricavelmente mesclados; culpa também de falbas psicológicas e intelectuais próprias, por onde se cedeu a chantagens emocionais. Trata-se de se 
afastar (apostasia cônscia de si) de certos vícios que a contrasociedade comunista favoreceu, e antes de tudo, da ignorância. Morin rememora sua antiga "atrofia mental". Alega, sem procurar isentar-se da responsabilidade, ignorância: "ignorando apressáo sobre os operários...ignorando que perseguíamos e denunciávamos os trotskistas", prometia a si mesmo que se o massacre dos oficiais poloneses em Katsyn durante a última guerra fosse obra dos russos e não dos alemães como acreditava, ele deixaria opartido ${ }^{23}$. Tornar-se mestre do próprio saber, informar-se pessoalmente, criar uma opiniáo própria representa, sob aquelas condiçôes, uma maneira de volta à Ítaca da realidade. A informaçáo eojuízo devem ser alcançados sem mediaçóes descontroladas, e permitir assim escapar a este ambiente intelectual a respeito do qual Morin pôde escrever:

(...) estava consciente no plano dos fatos. Mas meu entendimento comouma aranha enrolava em tornodofatobruto um emaranbado de raciocínios, explicações, justificativas, quefinalmente os amulava. Osfatospatenteavam-se, via-os, porém nãofalavam ${ }^{24}$.

O militantismo, no que concerne seus aspectos cognitivos, é comandado por raciocínios emaranbados, por casuísmos da razão, por um demagogismo da abstração que subvalorizam o alcance do empírico, do "fato bruto", na construção mental, subtraindo algo de sua função para a conformação do verdadeiro.

Oprocesso vai tão longe no caminbo da interdição subjetiva, que algumas dimensóes da consciência individual-ver, ouvir, tocar-, as mais imediatamente sensíveis, deixam de ser creditadas como aferidoras de verdade. Comunistas resistentes "viram" por exemplo, bomens como Rajk, Slansky, Artbur London, e tantos outros, combaterem o nazi-fascismo na clandestinidade, sacrificando-se, resistindo à tortura. A "verdade" nos processos intentados contra eles, será no entanto outra, transformados como foram em espióes a serviço dos Estados Unidos, em agentes da Gestapo, e em culpados de outros crimes pouco verossimelmente compatíveis entre si. Náo se pode, nestes termos, contar sobre o testemunbo de quem viu e ouviu. A relação a si é táo desvalorizada (mesmo quando náo passa da certeza de se ter visto o que se viu) que o vivido perde sua funçáo de critério de verdade. Esta 
será talvez a única sociedade em que o testemunbo bumano poderá ser francamente desdenbado, em que ojuizo sobre bomens despreza absolutamente o depoimento de outros.

Edgard Morin não esconde que ele e mais alguns dos seus companbeiros não ignoravam, antes mesmo do relatório Kroutchev, os crimes stalinistas, mas a "necessidade" destes crimes absolvia de antemão "um partido que não tem sempre razão, mas que reside na razão; um partido que julgávamos ontologicamente e não empiricamente" e convinba então que, "aparentemente", “formalmente”, a URSS era um Estado totalitário e podia ser comparada ao Estado nazista. Ora, a "auto-crítica" autobiográfica dos ex-stalinistas não encaminha senão um retorno a ompírico, reconstituindo a autoridade do fato: a realidade da intervenção soviética nos países da Europa central e a existência dos milhões de prisioneiros nos campos de concentração, a inverosimilhança das acusaçóes pronunciadas contra comunistas de velha cepa, bolcheviques (e stalinistas!) de primeira bora etc. Em aparente paradoxo, o empirismo só recobra seus direitos na reavaliação positiva da experiência subjetiva. A subjetividade reafirma a dignidade dos sentidos que, sabemos, necessitam para se constituírem confiáveis a confirmação de outros bomens.

Reencontrar a "si mesmo" como arrimo de aferição do real constitui uma regra de método, bem como uma experiência existencial, processo equivalente, se buscarmos um paralelofilosófico, à intuiçáo do Cogito cartesiano, procedimento à busca de uma certeza e certeza do procedimento.

Literalmente, para nossos autores, afastar-se do Partido e reavaliar a si mesmo significa voltar ao mundo, experimentar um renascimento, viver o momento em que olbos se abrem e enxergam; em que podemos nos prometer um recomeço providos de uma nova inocência no próprio modo de perceber e de sentir.

Dar destaque ao “eu”, nos moldes descritos pelos nossos autores, ao mesmo tempo que permite um novo acesso ao real e comporta uma nova construção do verdadeiro, parece também implicar na prioridade do núcleo moral comofundamento para a constituiçáo do "eu". Morin reitera-o ainda quando, em plena crise, mergulbado na dúvida a respeito da URSS, do seu partido, 
da própria conduta, em pleno drama de indecisáo intelectual e de impotência psicológica, partilhado entre suas "exigências presentes de verdade e de liberdade" e a "ideologia da (falsa) totalidade", escreve: "Eu me encontrava privado de ética, isto é, de vontade autônoma”. Náo saber regrar as condutas na ordem do bem (ou dos bens) resume uma impotência generalizada a existir. Os nossos três autores, assim que tomaram a decisão de deixar o Partido, ver-se-ão na obrigação de "reforjar uma moral" sentimento moral, escreve ainda este, constitui também um sentimento existencial, como o sentimento de liberdade que contradiz qualquer ciência, qualquer olhar sobre o passado bem como toda previsão do futuro, mas que é a seiva do presente vivido. $E$ esta seiva do vivido, coisa paradoxal, é a presença em nós de um dever ser, do ideal, da recusa, isto é, do virtual e do imaginário.

Oque a militância comunista portanto barra é não apenas a liberdade da pessoa mas também os impulsos originados pelo que parece dado, constitutivo, pela determinação identitária que aflora nas reações afetivas e morais. Todavia, as autobiografias náo desembocam sobre uma retórica da inefabilidade das diferenças entre os indivíduos, nem sobre o indizível dos sentimentos e muito menos se encerram sobre os solipsismos do "eu". Bem ao contrário, a subjetividade assim reivindicada afirma-se como capacidade prática, como apta e eficaz para se ocupar do bem comum. A verdade subsiste for a do Partido e o sentimento contribui para a possibilidade de se alçar à racionalidade e ao universalismo que esta postula. Morin substituiu uma visão teleológica da História ("era a única coisa que restava aos ateus revolucionários") por uma avaliaçãoforte do sentimento íntimo.

O essencial consiste em nunca descarregar sobre a História ofardo de nossa consciência; reside em trabalhar pelo bom lado da História, mesmo se a História está se fazendo do lado ruim.

O recurso ao sentimento moral colabora para suspender o evento na indeterminação: para a Resistência por exemplo-mesmo que os exércitos alemães ocupassem praticamente toda Europa e o Mediterrâneo em 1942 - batalhas tão somente haviam sido perdidas, a guerra por sua vez continuava. Que ofuturo bistórico náo seja pré-determinado implica, correlativamente, para 
o bomem moderno, uma capacitação a idealizá-lo. Implica, em decorrência, uma responsabilidade bistórica e a possibilidade de reter em nosso juízo o sentido dos acontecimentos.

\section{“UMA NÃO ESCOLHA QUE ESCOLHIA TUDO"}

A consciência não se assenta no vazio, nutre-se na interpretação dos autores, do roteiro bio-afetivo (desejos, carências, traumas), de toda sorte de marcas identitárias (meio social, momento bistórico). Advém no itinerário biográfico com a constituição afetiva. Mas reconbecer os afetos como partícipes da moralidade não significa outra coisa que implicar uma responsabilidade na própria constituição destes afetos. Claude Roy declara com certa ênfase ter feito duas descobertas: "A primeira, é que só a mim cabia, e sempre, a responsabilidade por mim (...) A segunda, é que podia sempre, para desapegar-me de mim, recorrer a mim mesmo'"26. Do próprio caráter, Roy decidiu fazer uma responsabilidade; defato, aceitar dizer que o caráter me dirige, me define ou me obriga, significaria na verdade aceitar desempenhar um papel, submeter-se (nem que fosse a si mesmo), antes que decidir.

Parei de vez de queixar-me das correntes de vento e de gemer que iria resfriar-me. Estava me tornando uma não escolba que escollhia tudo, e em primeiro higar, escollsia ser. Havia ainda muito caminho a percorrer. Mas aceitava enfim ser um bomem, isto é, não aceitar nada como consumado, salvo (...) considerar-me responsável. De tudo. Em primeiro lugar de mim mesmo.

Os termos em que Claude Roy e Edgard Morin expressam-se aqui são muito próximos. Este último-no momento em que deixa o partido-promete a si mesmo permanecer "comunista sempre, para sempre, mas livre, finalmente eu mesmo, responsável pormim mesmo". Ressoa claramente o tema da autenticidade e da referência a si como valor. É um valor que eu seja o que sou, que eu possa expressar o meu próprio eu verdadeiro. É uma alegria pertencerse. Há um orgulbo e uma promessa em se saber pronto ao repto contínuo a que a responsabilidade nos acua vida adentro. Há um desejo enfim que este eu possa dizer-se e que as palavras que o expressam possam ter acolhimento e, obviamente, respostas. 
A nova avaliaçáo da relação a si assume todo o seu relevo se nos remetermos à escolba sem saída à qual os militantes haviam sido acuados e nos perguntarmos como se pode exigir de alguém que arranque de si o que o tornou comunista, dizendo-lbe ao mesmo tempo que só assim permanecerá um bom comunista.

\section{O INDIVIDUALISMO E A VIDA COTIDIANA}

Aatração ideológica exercida pelocomumismoencontravauma sorte de correlato psicológico no pudor da dimensão pessoal, na negaçáo da propriedade de si, na recusa do possessivo e do pronome à primeira pessoa do singular. O Partido, ao contrário, somos nós e é nosso partido. Aos olbos comunistas, a subjetividade tenderia sempre a se refugiar na particularidade e no egotismo.

As narrativas vão encontraro tema do indivíduo ao evocaro da solidão e do isolamento: em nossos três textos, o indivíduo tomou a forma do bomem isolado dos outros e por isso, politicamente impotente. Deixar o partido constituía uma escolba difícil porque comportava o risco de uma incapacidade política, e porque quebrava laços de fraternidade.

Na realidade, como o admitem os próprios Roy e Morin, já no interior da "grande família", dúvidas, suspeitas, bostilidades frente às políticas do partido, provocavam o mais profundo isolamento. Morin, após confessar o quanto temia a solidão que acreditava "estéril, nefasta, inconsolável", dá-se conta que "não se trata de uma eventualidade a recusar. Ela se tornava mais densa a cada uma das minhas recusas, ao longo do meu silêncio"'27 : manter dúvidas sobre um aparelbo com pretensão a quase infalibilidade não pode senão isolar dos bomens que o compóem.

Logo, entretanto, a reflexão leva a reconbecer à solidão potencialidades intelectuais e morais não suspeitadas. Morin, mais uma vez, explicita-o inteiramente: "não pensava certamente que fosse correto exaltar os indivíduos contra os partidos. Se as organizaçóes políticas faziam política, o intelectual, este, "devia permanecer só, e só para dizer tudo"zs; Annie Kriegel ratifica:

Em um caminho que seria pornatureza solitário, nãopoderia tratarse senáo de pôr a limpo minha consciência bistórica e política. 
Estaria permanentemente à escuta dos eventos do mundo, o que megarantiria náodescolar doreal ${ }^{9}$

emais adiante,

(...) reconquistar ou antes conquistar minba total autonomia em todas as ordens - informação, elaboração, redação - , que concorrem à expressáo de uma opinião refletida; não pertencer à estrutura alguma de decisão que me engajasse às cegas e pesasse sobre a fiabilidade das minbas análises ${ }^{30}$.

Nestes termos, a solidáo reflexiva comanda algo como um regime de verdade, que subentende por sua vez qualidades morais; carece ter coragem para a solidão com ofim de atingir a plena verdade e a inteira lucidez. Odever sem transigência da verdadé é posto na conta única do indivíduo.

A conversáo à escuta de si comportou uma reavaliaçáo positiva do indivíduo, a solidão comportou ganbos intelectuais e beneficios éticos. Por outro lado, admitir o indivíduo parece favorecer uma volta ao senso comum quando privilegia o "aqui e agora". " $E$ boje, cansaço ou maturidade, penso também nopresente, no indivíduo presente. Manter boje o presente e ofuturo em relação de interdependência" ${ }^{\prime 1}$. Nas dimensóes do tempo, o presente se valoriza. Opassado náo pode, náo deve mais, tudo explicar; as condições sociais atrasadas da União Soviética nãojustificam os crimes stalinistas. Tampouco bastam as promessas de futuro. Que a dimensão subjetiva facilite esta reaproximação ao atual e ao concreto em detrimento das justificativas teóricas náo se correlaciona ao lugar único que o corpo e os sentidos ocupam no espaço e no tempo? Todo testemunbo, a autobiografia entre eles, conta o que viu, escutou e sentiu: overdadeiro se fazmais empiricamente sensual, e a moral se detém mais imediatamente nos sofrimentos concretos, coletivos ou singulares. "Numa palavra, torno-me cada vezmais sensível aos problemas concretos da liberdade”, escreve Morin ${ }^{32}$.

Igualmente, a vida cotidiana passa a ser estimada de uma maneira nova. A historiadora, o sociólogo e o escritor aprendem o gosto da vida civil, aquela que constitui, em épocas de paz, a sorte comum dos bomens comuns. "O verão de 1950 trouxe-me finalmente uma profissão”, regozija-se Morin ${ }^{33}$. Exercer uma pro- 
fissão não é mais considerado como marca depreciada de acomodação, tornou-se um forma de expressáo e de realização de si, à medida das individualidades, um modo de enriquecimento pessoal e de reconbecimento social ${ }^{4}$. A valorizaçáo do trabalbo na vida cotidiana, onde lemos desde Max Weber a estampa subversiva da reforma protestante, é reposta; admite-se igualmente a importância estruturante dos laços afetivos e inter-subjetivos para a identificação de si. Profissão e família constituem bens, e a realizaçấo de cada um, nestes domínios, adquire valor moral. Annie Kriegel descreve com ênfase suas reações após ter sido levada a deixar opartido comunista francês:

Longe de me sentir desocupada, de languescer, diminuídaportanta nostalgia e apavorada diante do tempo a preencher, reencontrei com delícia os trabalhos e os dias onde se vive no ritmo próprio, estestrabalhos nem entediantes nem fáceis, estes dias onde gozava de um privilégio inestimável: estudar na minha mesa, na minha casa, minhas crianças brincando ao redor de mim.

Felicidade, outrora tão suspeita, de pertencer-se e de particularizar-se na posse.

A vida privada parecerá quiçá pouco exaltante, sobremodo se contraposta à auréola beróica do civismo patriótico. Lembro apenas o conteúdofortemente democrático da valorização da vida cotidiana; só quando o trabalbo e as dimensóes da vida privada e intima passam a ser valorizados, puderam e poderão as atividades do dia-a-dia gerar, em todos, auto-estima e auto-gratificação.

A construção secular da subjetividade moderna, pela qual se integra a intuição ao mesmo tempo afetiva, moral e cognitiva dos bomens comuns, é contemporânea da construção democrática. Todo bomem pode sediar a política exatamente porque possui um corpo, porque é um existente vivo e bistórico, porque está presente no mundo: eis o que os partidos comunistas náo conseguem admitir na ordem de suas razóes.

Acompanhamos uma narrativa toda ela pontuada de comentários e análises; tais escritos, tentei demonstrar, visavam decidir quem é, quem pode ser, quem deve ser, sujeito de conbecimento e sujeito moral. O gesto usurpador dos partidos comunistas, ao se declararem subjetividades totais, absolutas, suportes da obje- 
tividade bistórica, tendeu a alucinar, ao pé da letra, algumasmentes militantes (Roy e Morin, aqui, bem mais que Kriegel). As subjetividades individuais configuram, então, muito mais que adversários ideológicos potenciais. Representam ameaças cujo estatuto verdadeiro é ontológico: eis onde irrompe, parece lícito afirmar, oprincípio totalitário.

\section{Notas:}

${ }^{1}$ RIGOULOT, Pierre. Les paupières lourdes. Les français face au Goulag: aveuglement et indignations. Éditions Universitaires, Institut d'Histoire Sociale/Fondation Bouvarine, 1991.

${ }^{2}$ Otermo contra-sociedade, que fez escola, cunbado por Annie Kriegel remete ao mundo ideológico à parte, em que os Partidos Comunistas vivem, ao visarem ofim da sociedade à qual, bem ou mal, pertencem.

${ }^{3}$ De MORIN, Edgard. Auto-Critique. Paris, Seuil, 1959. De KRIEGEL, Annie. Ce que j'ai cru comprendre. Paris, Laffont, 1991. E a trilogia de ROY, Claude. Moi,je. Paris, Gallimard, 1976; Nous, 1972 e Somme toute, 1976. Morin, sociólogo bastante conbecido no Brasil, nasceu em Paris em 1921. Adere ao partido comunista em 1941 na Resistência; é excluído em 1951 por oposição ao stalinismo. Diretor da revista Arguments (1957-1963). Publica posteriormente obra alentada, integrando a École des Hautes Études en Sciences Sociales: L'bomme et la mort, Introduction à une politique de l'bomme. Paris, Seuil, 1970; Le Paradigme perdu: la nature humaine. Paris, Seuil, 1973; L'esprit du temps. Paris, Grasset, 1975; La métbode. Paris, Seuil, 1977, Pour sortir du XXeme siècle. Paris, FNathan, 1981; Science avec Conscience. Paris, Seuil, 1990, entre outros. Annie Kriegel tem 13 anos em 1939, permanece na Paris ocupada até 1942. Refugiada em Grenoble com seus pais até 1944, sob ocupação italiana e posteriormente alemá, participa da Resistência, integrada naJuventude Comunista - Mão de obra imigrada (JC-Moi)-até a Libertação. Opera sua "volta" crítica, quando deixa o Partido, desde os anos 1954-1955, tendo ocupado cargos bastante importantes no seu interior (direção de Clarté, jornal dos Estudantes Comunistas, profissionalizada, delegada federal na seçáo do LX, Paris, enfim membro do Bureau de la Fédération de la Seine). Recebida no concurso de Agregação, escreve uma tese sobre o movimento operário francês; professora e pesquisadora em Reims e Nanterre de História Contemporânea; ocupará durante longo prazo uma coluna no Figaro, prestigioso jornal conservador É a primeira bistoriadora francesa do comunismo no seu pais (Aux origines du communisme français, Communismes aux miroirs français). Faleceu na primavera de 1996. Claude Roy, nascido em 1915, soldado em 1939, feito prisioneiro no início da guerra, consegue escapar; resistente, adere ao Partido em 1946 e rompe em 1956. Crítico, romancista, poeta e ensaísta fecundo, bastante notório na França.

${ }^{4}$ GAUCHET, M. “Le mal démocratique”. In Esprit, out. 1993.

${ }^{5}$ Embora Kriegel náo deixe de evocar inchusive estestempos com alguma melancolia.

${ }^{6}$ Ver LEJEUNE, P. L'autobiographie en France. Paris, A. Colin, 1971. 
${ }^{7}$ ROY, C. op.cit. Charles Taylor escreve com justeza que "law is what I must obey. It may confer on me certain benefits, bere the immunity that my life, too, is to be respected; but fundamentally I am under law. By contrast, a subjective right is something which the possessor can and ought to act on to put it into effect. To accord you an immunity, formely given you by natural law, in the form of a natural right is to give you a role in establishing and enforcing this immunity. Your concurrence is now necessary, and your degrees offreedom are correspondingly greater." The Sources of the Self. The Making of the Modern Identity. Cambridge University Press, 1989, p. 11.

${ }^{8}$ Primeiro da série de grandes processos no pós-guerra em países da Europa do Leste. Ocorrido em Budapeste no fim da década de 1940, montado a partir de Moscou, tencionava denunciar e prevenir com o terror a renovação dos males do "nacionalismo estreito" que haviam conduzido ao divisionismo de Tïto na Iugoslávia. Rajk era ministro do Interior, com toda a polícia húngara sob suas ordens, e secretário do Partido quando foi preso e condenado junto com outros comunistas da velha tradição, igualmente insuspeitos; militante desde ajuventude, um dos quadros comunistas na guerra civil espanbola, internado em 1939 no campo francês de Vernet, de onde via Alemanha, reintegra a Hungria sob ordem do Partido comunista. "Confessa”, admite ter sido espião alemão ("Fui dedo-duro desde 1939") e desertor ("Em 1939, desertei, e fugi da Espanba"). Ver GARAY, Sandor. Volontaires pourla potence. Techmique des procès soviétiques. Paris, Ed.Beyeré, 1950.

${ }^{9}$ MORIN, Edgard. op. cit., p. 07.

10 “(...) naissant de la démocratie, prospérant en son sein, la baine du bourgeois n'est qu'en apparence la haine de l'autre. En son centre, elle est la baine de soi." FURET, F Le passé d'une illusion. Essai sur l'idée communiste au XXème siècle. Paris, R.Laffont/Calman Levy, 1995, p.29.

${ }^{11}$ MORIN, Edgard. op. cit., p. 16.

${ }^{12}$ Idem, p. 248.

${ }^{13}$ ROY, Charles. op. cit., p. 208.

${ }^{14}$ KRIEGEL, Annie. op. cit., p. 195.

${ }^{15}$ Idem, p. 763.

16 "Le temps devient temps humain dans la mesure où il dessine les traits de l'expérience temporelle”. RICOEUR, P. Temps et Récit. Paris, Seuil, 1983, p. 17.

${ }^{17}$ MORIN, Edgard. op. cit., p. 41.

${ }^{18}$ Idem, p. 41.

${ }^{19}$ Idem, p. 186.

${ }^{20}$ Idem, p. 150.

${ }^{21}$ Idem, p. 126.

${ }^{22}$ KRIEGEL, Annie. op. cit., p. 672.

${ }^{23}$ Katsyn, lugarejo russo, no oeste de Smolensk. Os cadáveres de 4.500 oficiais poloneses abatidos em 1940-1941 foram descobertos no lugar. Os soviéticos admitiram, após anos de denegação, a responsabilidade do crime que recaíra sobre osalemães.

${ }^{24}$ MORIN, Edgard. op. cit., p. 118.

${ }^{25} \mathrm{Idem}$. 
26 “La première, c'est que je ne pouvais m'en prendre qu'à moi de moi (...) La seconde, c'est que je pouvais toujours m'en prendre à moi pour me déprendre de moi”. ROY, Claude. op. cit., p. 343.

${ }^{27}$ MORIN, Edgard. op. cit., p. 159.

${ }^{28}$ Idem, p. 180.

${ }^{29}$ KRIEGEL, Annie. op. cit., p. 612.

${ }^{30}$ Idem, p. 780.

${ }^{31}$ Idem.

${ }^{32}$ MORIN, Edgard. op. cit., p. 241.

33 Idem, p. 183.

${ }^{34}$ Logo após a Liberação, Morin considerava um emprego na imprensa burguesa como um desmoralizador acumpliciamento aostatus-quo. 